\title{
KOMPARASI PERENCANAAN KONSTRUKSI SERTA RENCANA BIAYA PEMBANGUNAN GEDUNG KONSTRUKSI BETON DAN GEDUNG KONSTRUKSI BAJA KOMPOSIT
}

\author{
${ }^{1}$ Eri Rihandiar, ${ }^{2}$ M. Robby Indrawan \\ Program Studi Teknik Sipil Fakultas Teknik Universitas Suryakancana \\ eri.rihandiar@yahoo.com
}

\begin{abstract}
Abstrak
Indonesia merupakan salah satu Negara yang berada di zona subduksi beberapa lempeng bumi, sehingga Indonesia merupakan salah satu Negara yang rawan terhadap bencana gempa bumi. Indonesia juga merupakan salah satu dari sekian banyak Negara berkembang yang sedang giat melakukan banyak pembangunan infrastruktur gedung dan jalan raya. Untuk infrastruktur gedung yang dibangunan secara bertingkat haruslah memenuhi persyaratan ketahanan terhadap gempa bumi yang mungkin terjadi selama umur layan gedung.

Struktur baja profil memiliki kelebihan dalam keseragaman bentuk dan jaminan mutu yang lebih tinggi dibandingkan struktur beton bertulang, selain itu struktur baja profil memiliki kekuatan yang lebih daktail. Masa konstruksi yang singkat juga menjadi salah satu pertimbangan dari pemilihan struktur baja profil.

Perbandingan dari penggunaan struktur baja dan struktur beton bertulang dikaji dalam Tugas Akhir ini. Fokus yang dikaji adalah perbandingan dimensi elemen struktur menggunakan struktur baja komposit dan dimensi elemen struktur menggunakan struktur beton bertulang. Setelah dimensi desain baru yang menggunakan struktur baja komposit didapatkan, kemudian dibandingkan biaya pekerjaan elemen struktur primer (pelat, balok anak, balok induk, kolom dan pondasi) berdasarkan desain baru yang menggunakan baja komposit dengan biaya pekerjaan elemen struktur primer yang menggunakan beton bertulang.
\end{abstract}

Kata Kunci : zona subduksi, gempa bumi, beton bertulang, baja komposit, biaya

\section{PENDAHULUAN}

Dalam pembangunanan struktur gedung bertingkat, banyak sekali yang menggunakan beton bertulang sebagai struktur utama dari gedung yang dibangun tersebut. Namun struktur beton bertulang sendiri masih memiliki kekurang, diantaranya adalah masa konstruksi yang lama dan mutu yang tidak terjamin. Berbeda dengan beton bertulang, konstruksi yang menggunakan struktur baja profil memiliki mutu yang sesuai dengan standar dan juga masa pengerjaan konstruksi yang lebih cepat dibandingkan beton bertulang.

Selain hal tersebut, struktur baja profil memiliki kekuatan yang lebih daktail dibandingkan beton bertulang. Kelebihan ini dapat membuat konstruksi mengalami simpangan pasca elastik yang besar secara berulang kali dan bolak-balik akibat gempa yang menyebabkan terjadinya pelelehan pertama, sambil mempertahankan kekuatan dan kekakuan yang cukup, sehingga struktur tersebut tetap berdiri, walaupun sudah berada dalam kondisi ambang runtuh.

\section{TINJAUAN PUSTAKA}

Menurut SNI 03-1726-2002 "Tata Cara Perencanaan Ketahanan Gempa Untuk Bangunan Gedung", Kabupaten Cianjur masuk ke dalam wilayah gempa IV atau masuk daerah gempa sedang. Karena Kabupaten Cianjur masuk ke dalam zona gempa sedang, maka struktur bangunan gedung bertingkat harus direncanakan kuat terhadap beban gempa periode ulang 500 tahun, sehingga proses perencanaan struktur gedung sangat mempengaruhi kinerja struktur pada saat terjadi gempa besar.

Gedung Dinas Pertanian Tanaman Pangan dan Holtikultura Kabupaten Cianjur memiliki jumlah tingkat sebanyak tiga tingkat, dengan menggunakan struktur beton bertulang sebagai struktur gedung tersebut. Dengan menggunakan beton bertulang, tentunya waktu pelaksanaan menjadi lebih banyak dibandingkan dengan penggunaan struktur baja profil. Mutu beton yang digunakan dalam pembangunan gedung ini memiliki kuat tekan karakteristik K-250, atau setara dengan $20 \mathrm{MPa}$. 
Dalam design baru yang akan dilakukan, struktur balok dan kolom akan diganti menggunakan profil baja dengan mutu ST 37 yang memiliki kuat leleh (fy) $240 \mathrm{MPa}$ dan kuat putus (fu) $370 \mathrm{MPa}$, sedangkan untuk pelat lantai sendiri akan menggunakan pelat bondek yang ditoping oleh beton. Setelah ukuran profil baja didapatkan, akan dilakukan perencanaan sambungan struktur (sambungan balok-balok dan sambungan balokkolom) dan juga perencanaan pondasi.

\section{METODOLOGI PENELITIAN}

Metodologi yang digunakan dalam modifikasi design Gedung Dinas Pertanian Tanaman Pangan dan Holtikultura Kabupaten Cianjur yang menggunakan konstruksi baja antara lain :

\section{a. Pembebanan}

Yaitu menentukan jenis dan besarnya bebanbeban yang akan bekerja pada bangunan tersebut.

\section{b. Preliminary design}

Yaitu menetapkan taksiran awal dari dimensi atau ukuran bagian-bagian bangunan yang terdiri dari pelat, balok dan kolom. Preliminary design ini dihitung berdasarkan beban-beban yang bekerja pada bangunan.

\section{c. Pemodelan struktur}

Memodelkan struktur dalam bentuk tiga dimensi menggunakan bantuan software Extended Three Dimensional Analysis of Building Systems (ETABS) v 9.7.2.

\section{d. Analisa struktur}

Melakukan analisa struktur dari pemodelan yang telah dibuat. Analisa struktur dilakukan dengan bantuan software ETABS v 9.7.2. Analisa struktur ini bertujuan untuk mengetahui respons struktur akibat bekerjanya gaya luar pada bangunan. Gaya luar yang akan diperhitungkan adalah gaya vertikal dari beban mati dan beban hidup, serta gaya horisontal/lateral akibat beban gempa.

\section{e. Menentukan profil balok dan kolom}

Menentukan dimensi elemen-elemen struktur gedung yang direncanakan, seperti profil balok dan kolom pada seluruh bangunan dengan menggunakan profil baja yang paling aman dan ekonomis.

\section{f. Perencanaan pondasi}

Merencanakan sub structure yang paling cocok dalam pembangunan Gedung Dinas Pertanian Tanaman Pangan dan Holtikultura Kabupaten Cianjur, dengan mempertimbangkan faktor keamanan, beban yang diberikan oleh upper structure dan juga mempertimbangkan efisiensi dari penggunaan jenis pondasi yang direncanakan.

\section{g. Perbandingan design dan biaya}

Membuat perbandingan antara design elemenelemen struktur baru yang menggunakan konstruksi baja profil dengan design yang terdahulu yang menggunakan konstruksi beton bertulang. Biaya yang dikeluarkan untuk design yang baru dibandingkan dengan biaya design yang sudah ada, kemudian diambil kesimpulan dari perbandingan design tersebut.

Peraturan yang digunakan dalam perencanaan gedung ini, antara lain :

1. SNI Gempa : Pedoman Perencanaan Ketahanan Gempa untuk Struktur Bangunan Gedung (SNI 03-1726-2002).

2. SNI Baja : Tata Cara Perencanaan Struktur Baja untuk Bangunan Gedung (SNI 03-17292002).

3. SNI Beton : Tata Cara Perhitungan Struktur Beton untuk Bangunan Gedung (SNI 032847-2002).

4. Pembebanan : Pedoman Perencanaan Pembebanan untuk Rumah dan Gedung (SNI 03-1727-1989).

Informasi Umum Bangunan Gedung ini terdiri dari 3 tingkat, dengan tinggi masing-masing tingkat setinggi 3,6 meter. Berikut adalah informasi mengenai bangunan tersebut :

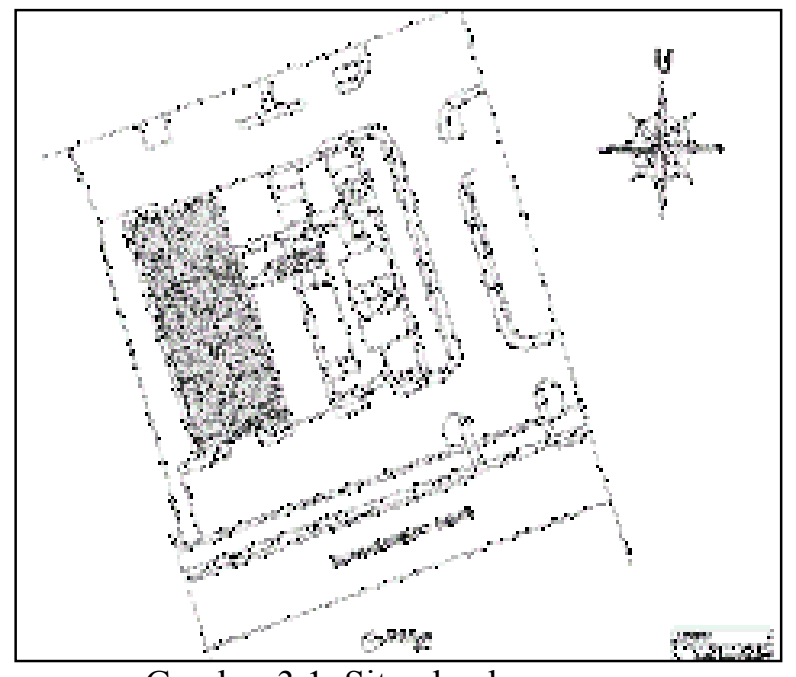

Gambar 3.1. Site plan bangunan 


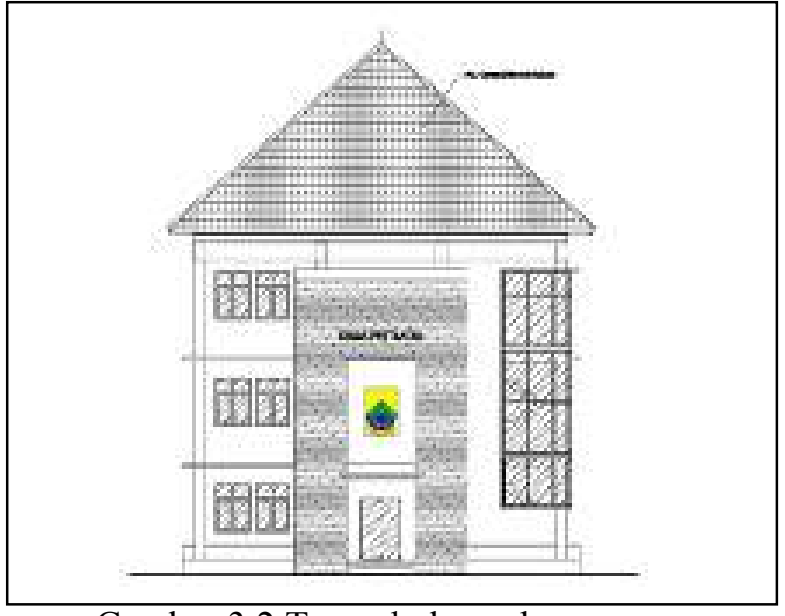

Gambar 3.2 Tampak depan bangunan

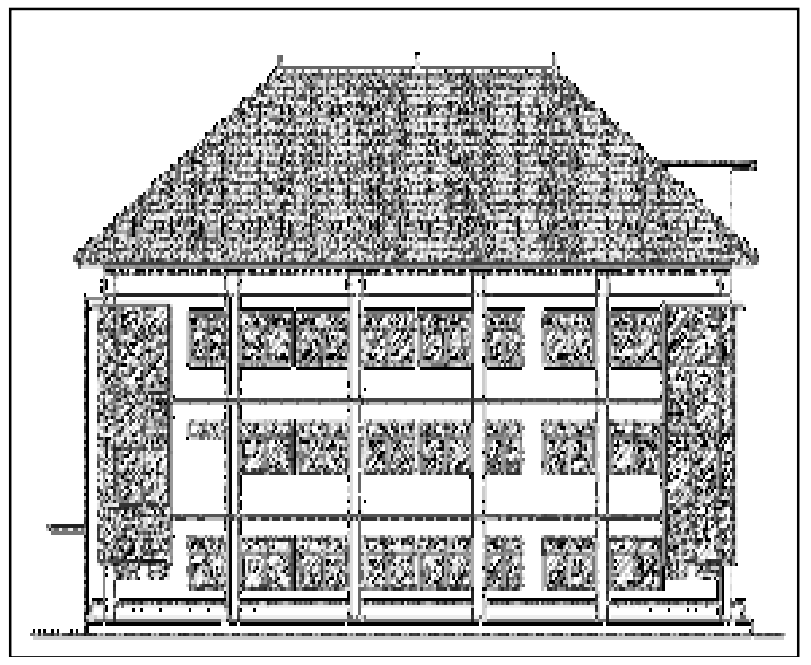

Gambar 3.3 Tampak samping kanan bangunan

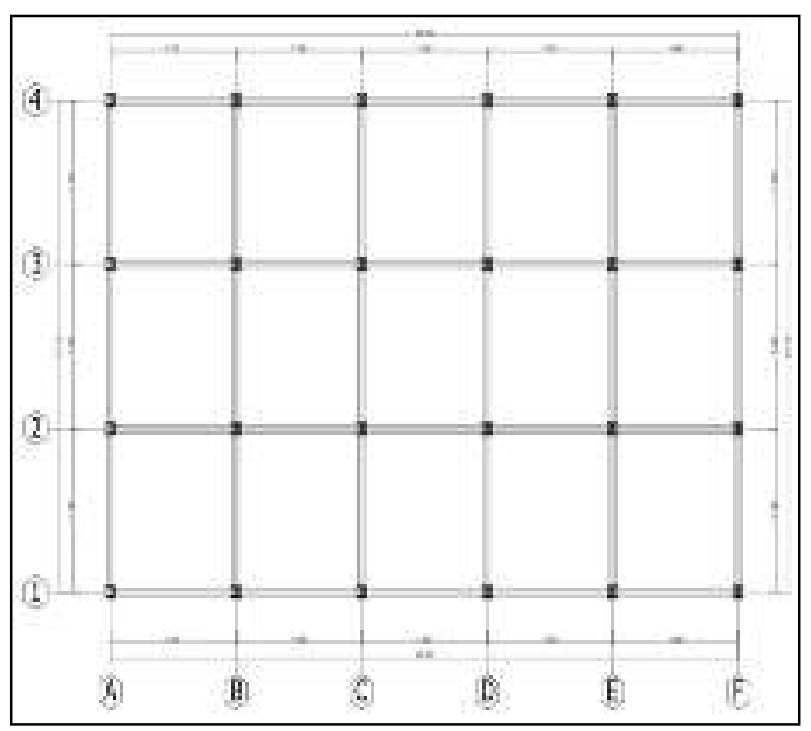

Gambar 3.4 Denah struktur lantai 1

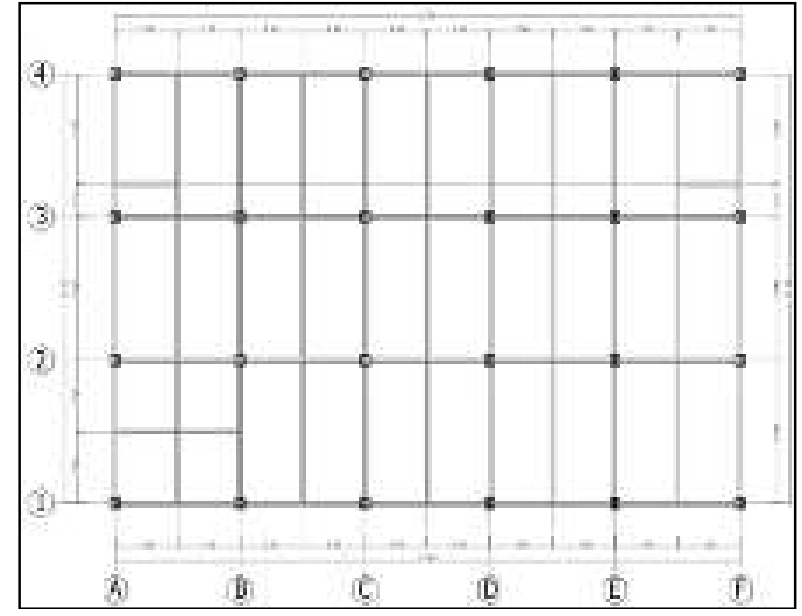

Gambar 3.5 Denah struktur lantai 2

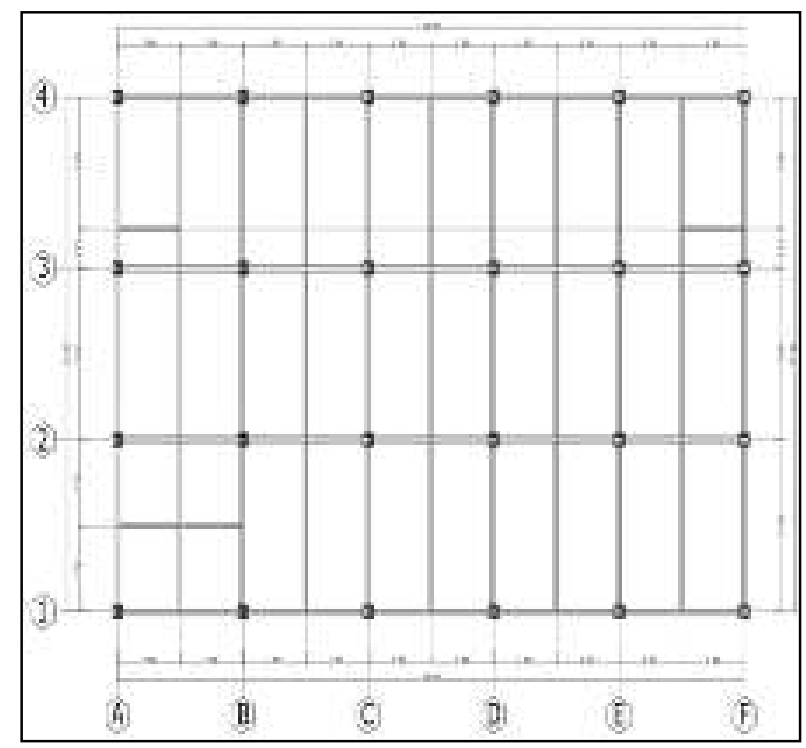

Gambar 3.6 Denah struktur lantai 3

\section{ANALISIS DATA}

A. Preliminary Design

Berikut ini merupakan hasil dari proses preliminary design yang telah dilakukan. Hasil preliminary design selanjutnya dimasukan ke dalam software ETABS v.9.7. 


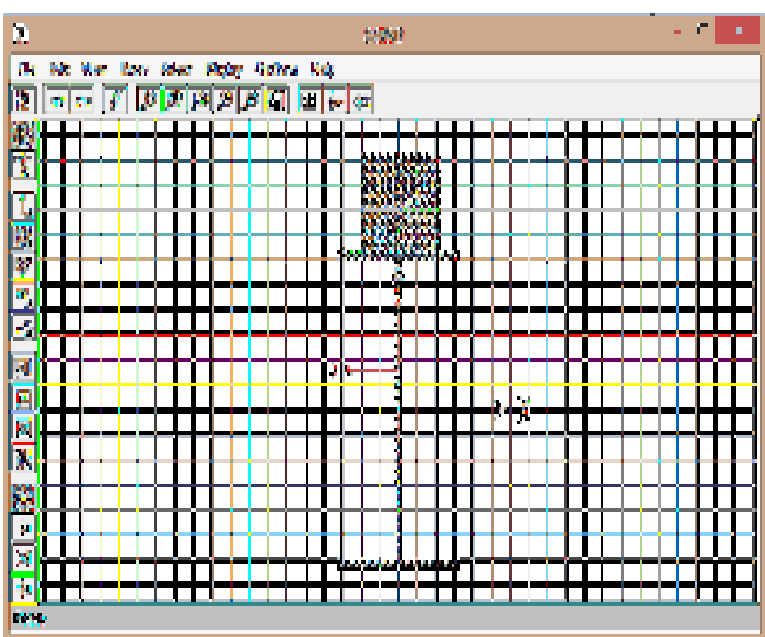

Gambar 4.1. Profil WF 300.150.6,5.9 komposit (balok induk) input ETABS v.9.7

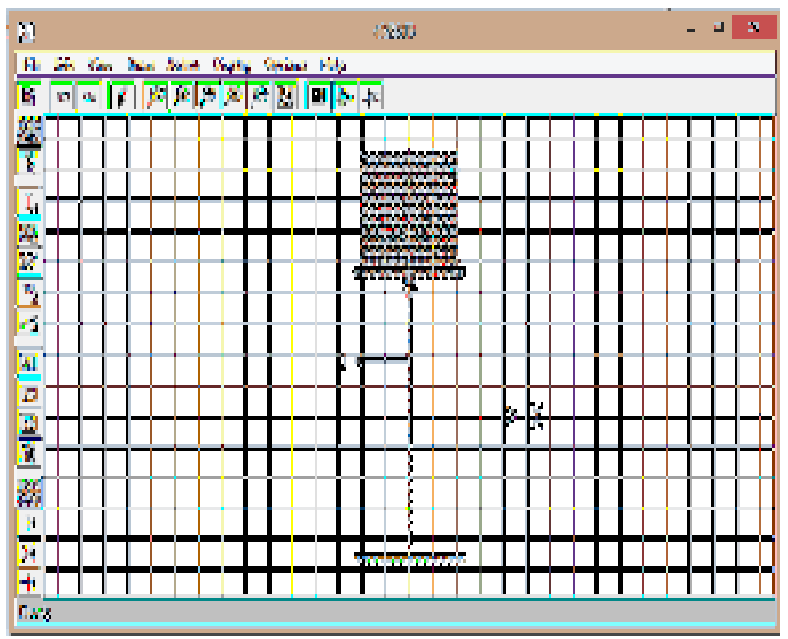

Gambar 4.2. Profil WF 200.100.5,5.8 komposit (balok anak) input ETABS v.9.7.2

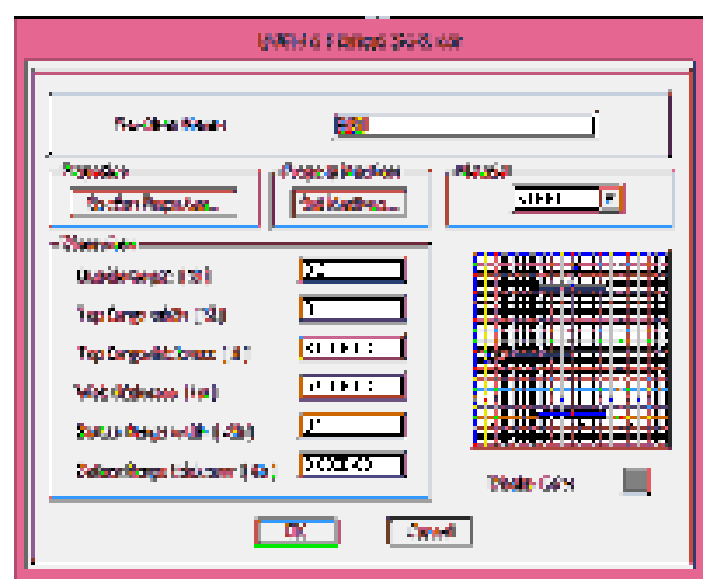

Gambar 4.3. Profil WF 200.100.5,5.8 (RB 1) input ETABS v.9.7.2

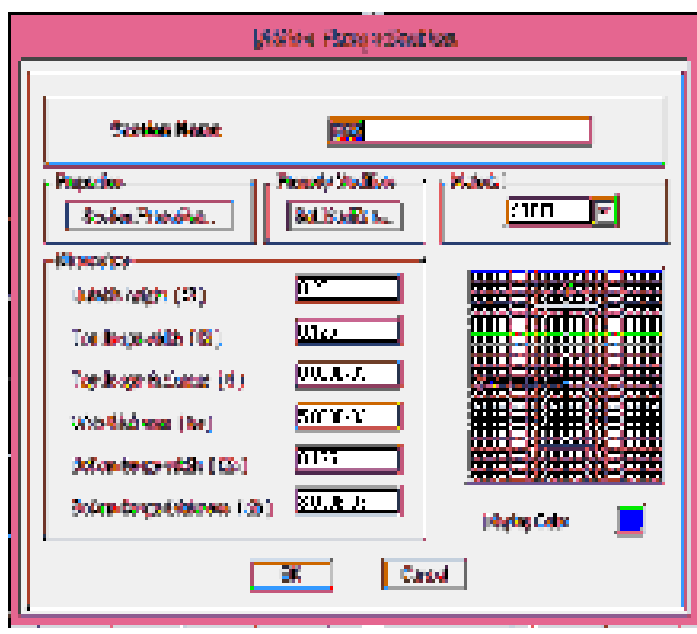

Gambar 4.4. Profil WF 250.125.5.8 (RB 2) input ETABS v.9.7.2

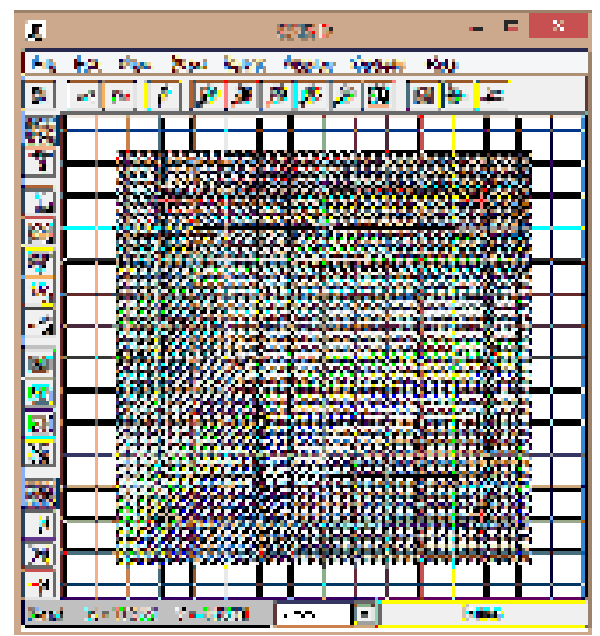

Gambar 4.5. Profil WF 200.200.12.12 (kolom komposit) input ETABS v.9.7.2

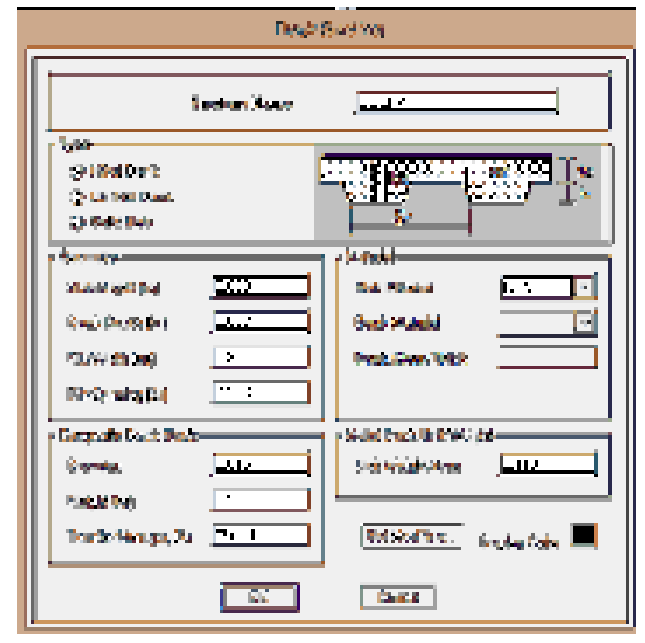

Gambar 4.6. Penampang pelat bondek input ETABS v.9.7.2 


\section{B. Pemodelan Struktur}

Pemodelan struktur bangunan gedung menggunakan software ETABS v.9.7.2.

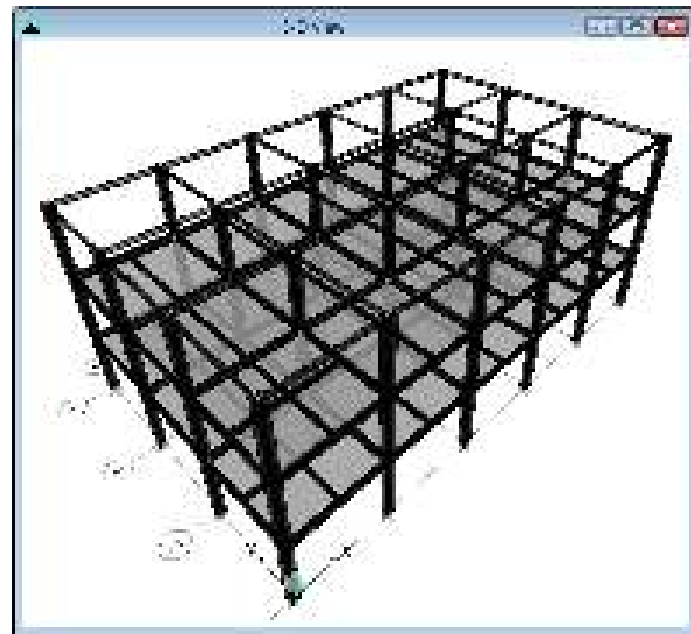

Gambar 4.7 Pemodelan 3 dimensi ETABS v.9.7.2

\section{Pemodelan Struktur}

\section{Bentuk Bangunan}

Struktur bangunan Gedung Dinas Pertanian Tanaman Pangan dan Holtikultura Kabupaten Cianjur terdiri dari 3 tingkat, dengan bagian atap menggunakan kuda-kuda baja profil dengan jenis penutup atap genteng. Dalam perencanaan gedung ini, struktur bangunan dan struktur atap direncanakan secara terpisah, dimana beban dari kuda-kuda baja disalurkan sebagai beban terpusat di bagian ring balok atau kolom tingkat ketiga.

Tinggi struktur gedung tanpa dari taraf penjepitan adalah 10,8 meter, dalam perhitungan beban gempa tinggi tersebut dijadikan sebagai acuan dalam perhitungan waktu getar alami struktur (T). Struktur gedung yang sederhana dan beraturan memungkinkan untuk menggunakan hanya metode analisa statik ekivalen dalam tinjauan pembebanan gempa rencana.

\section{Sistem Struktur}

Struktur gedung yang direncanakan dimodelkan sebagai Sistem Rangka Pemikul Momen (SRPM) atau Frame Resisting Moment (FRM). Struktur yang gedung ini dianalisa terhadap pengaruh gempa, dimana struktur ditinjau secara 3 dimensi yang terjepit pada taraf lantai dasar. Gedung yang direncanakan tidak perlu menggunakan analisa P-delta, dikarenakan tinggi gedung yang kurang dari 40 meter dari penjepit pada taraf lantai dasar.

Dengan anggapan lantai tingkat (juga atap beton dan lantai dengan ikatan) bekerja sebagai diafragma, yang artinya memiliki kekakuan yang besar sekali di dalam bidangnya, maka terhadap beban gempa setiap lantai tingkat itu memiliki 3 derajat kebebasan, yaitu translasi dalam arah masingmasing sumbu koordinat dan rotasi melalui pusat rotasi lantai tingkat itu. Ketiga derajat kebebasan ini menentukan pembagian beban gempa horisontal kepada seluruh sistem struktur tingkat, sebagaimana halnya pada struktur 3 dimensi secara umum.

\section{Komponen - Komponen Struktur}

\section{Balok komposit}

Pada pemodelan struktur, digunakan pelat lantai bondek yang ditoping oleh beton. Penggunaan bondek ini ditujukan sebagai pengganti bekisting dan tulangan positif pada pelat lantai, sedangkan untuk tulangan negatif pelat digunakan tulangan wiremesh yang telah dipabrikasi di pabrik. Kekakuan pelat lantai ditinjau dan pelat lantai berfungsi sebagai penyalur beban-beban ke balok anak maupun balok induk. Balok baja dan pelat lantai dihubungkan dengan shear connector, sehingga balok tersebut berperilaku sebagai balok komposit.

Menurut pasal 10.5 (1), Tata Cara Perhitungan Struktur Beton untuk Bangunan Gedung SNI 032847-2002, nilai modulus elastisitas beton dengan massa jenis beton diantara $1.500 \mathrm{~kg} / \mathrm{m} 3$ dan 2.500 $\mathrm{kg} / \mathrm{m} 3$ nilai modulus elastisitas beton (Ec) dapat diambil sebesar (wc)1,5 0,043 $\sqrt{\mathrm{fc}}$ ' (dalam MPa. Untuk beton normal Ec dapat diambil sebesar $\left.4.700 \sqrt{ } \mathrm{fc}^{\prime}\right)$, sehingga nilai modulus elastisitas beton yang digunakan $(\mathrm{Ec})=21019 \mathrm{MPa}$. Sedangkan modulus elastisitas baja profil (Es) diambil sebesar $200.000 \mathrm{MPa}$.

Dalam input penampang di software ETABS v.9.7.2, penampang balok yang digunakan adalah balok komposit ekivalen, dimana untuk input penampang balok baja diperhitungkan bekerja bersama dengan lebar pelat bondek, sehingga lebar efektif dari balok komposit dibagi dengan nilai perbandingan modulus elastisitas baja dan beton (n) .

Berikut ini adalah perhitungan momen inersia balok anak komposit dan balok induk komposit : 


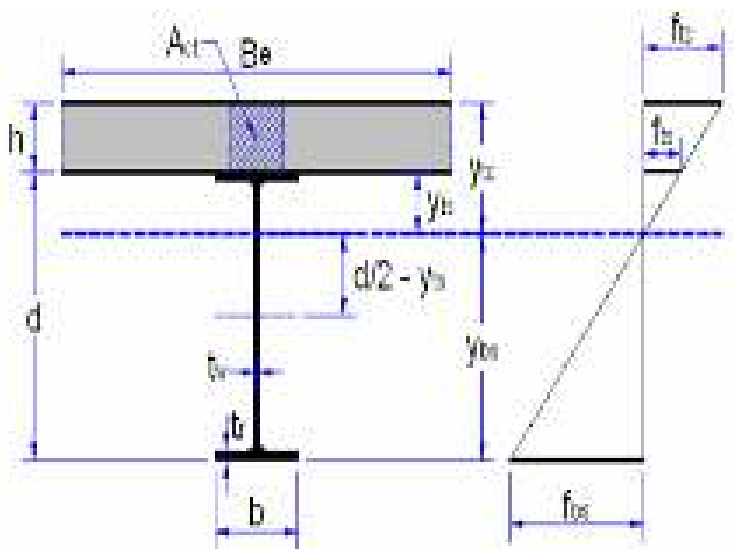

Gambar 4.8. Bagian-bagian pada balok komposit

Perhitungan momen inersia balok anak komposit: Menghitung rasio perbandingan modulus elastisitas bahan (n) : n=E_s/E_s, dimana $E s=$ $200.000 \mathrm{MPa}$ dan $\mathrm{Ec}=21.019 \mathrm{MPa}$

$\mathrm{n}=(200.000 \mathrm{MPa}) /(21.019 \mathrm{Mpa})=9,515$

Menghitung luas penampang beton transformasi balok anak komposit (Act) :

A_ct $=($ be $\times$ h $) / \mathrm{n}$

A_ct $=(1.250 \mathrm{~mm} \times 120 \mathrm{~mm}) / 9,515$

$=15.764,28 \mathrm{~mm}^{\wedge} 2$

Menghitung luas penampang komposit balok anak komposit (Acom) :

A_com $=$ A_p + A_ct

A_com $=2.716 \mathrm{~mm}^{\wedge} 2+15.764,28 \mathrm{~mm}^{\wedge} 2$

A ${ }^{-}$com $=18.480,280 \mathrm{~mm}^{\wedge} 2$

Mencari jarak garis titik netral terhadap sisi bawah balok anak komposit (ybs) :

A_(com ) x y_bs $=$ A_p $\mathrm{x} \mathrm{d} / 2+\mathrm{A} \_\mathrm{ct} \times(\mathrm{d}+\mathrm{h} / 2)$

$\mathrm{y} \_\mathrm{bs}=\left(\mathrm{A} \_\mathrm{p} \times \mathrm{d} / 2+\mathrm{A} \_\mathrm{ct} \times(\mathrm{d}+\mathrm{h} / 2)\right) / \mathrm{A} \_(\mathrm{com})$

y_bs $=\left(\left(2.716 \mathrm{~mm}^{\wedge} 2 \times(200 \mathrm{~mm}) / 2\right)+(15.764,28\right.$

$\left.\left.\mathrm{mm}^{\wedge} 2 \times(200 \mathrm{~mm}+(120 \mathrm{~mm}) / 2)\right)\right) /(18.480,280$

$\mathrm{mm}^{\wedge} 2$ ) y_bs $=236,485 \mathrm{~mm}$

Mencari jarak sisi atas profil baja terhadap garis netral balok anak komposit (yts) :

y_ts $=d-y_{-} b s$

y_ts $=200 \mathrm{~mm}-236,485 \mathrm{~mm}$

y_ts $=-36,485 \mathrm{~mm}$

Mencari jarak sisi atas slab beton terhadap garis netral balok anak komposit (ytc) :

y_tc $=\mathrm{h}+\mathrm{y}$ _ts

y_tc $=120 \mathrm{~mm}-36,485 \mathrm{~mm}$

$\mathrm{y}_{\mathrm{t}} \mathrm{tc}=83,515 \mathrm{~mm}$

Mencari momen inersia penampang balok anak komposit (Icom) :

I_com $=\left(1 \times\right.$ be $\left.\times h^{\wedge} 3\right) /(12 \times n)+A$ ct $\times\left(y \_t c-\right.$ $\mathrm{h} / 2)^{\wedge} 2+\mathrm{I} \_\mathrm{p}+\mathrm{A} \_\mathrm{p} x\left(\mathrm{~d} / 2-\mathrm{y} \_\mathrm{ts}\right)^{\wedge} 2$

I_com $=(1 \times 1250 \mathrm{~mm} x \bar{\square}(120 \mathrm{~mm}) \rrbracket \wedge 3) /(12 \mathrm{x}$

$9,515)+15.764,28 \mathrm{~mm}^{\wedge} 2 \quad \mathrm{x}(83,515 \mathrm{~mm}-(120$ $\mathrm{mm}) / 2)^{\wedge} 2+18.400 .000 \mathrm{~mm}^{\wedge} 4+2.716 \mathrm{~mm}^{\wedge} 2 \mathrm{x}$ $\left(200 / 2 \mathrm{~mm}^{\wedge} 2-(-36,485 \mathrm{~mm})\right)^{\wedge} 2$

I_com $=96.628 .509,270 \mathrm{~mm}^{\wedge} 4$

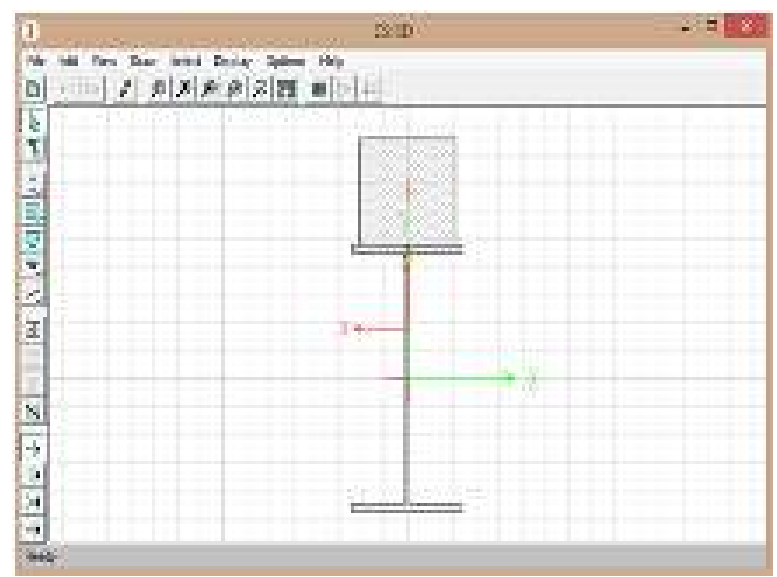

Gambar 4.8 Profil balok anak komposit yang digunakan (WF 200.100.5,5.8)

Perhitungan momen inersia balok induk komposit:

Menghitung rasio perbandingan modulus elastisitas bahan (n) : n=E_s/E_s, dimana Es = $200.000 \mathrm{MPa}$ dan $\mathrm{Ec}=21.019 \mathrm{MPa}$

$\mathrm{n}=(200.000 \mathrm{MPa}) /(21.019 \mathrm{MPa})=9,515$

Menghitung luas penampang beton transformasi balok induk (Act) : A ct $=($ be $x \mathrm{~h}) / \mathrm{n}$

A_ct $=(1.250 \mathrm{~mm} \times 120 \mathrm{~mm}) / 9,515=15.764,28$ $\mathrm{mm}^{\wedge} 2$

Menghitung luas penampang balok induk komposit (Acom)

A $c o m=A$ p + A ct

A_com $=4.678 \mathrm{~mm}^{\wedge} 2+15.764,28 \mathrm{~mm}^{\wedge} 2$

A_com $=20.442,28 \mathrm{~mm}^{\wedge} 2$

Mencari jarak garis titik netral terhadap sisi bawah balok induk komposit (ybs) :

A_(com ) $x$ y_bs $=A \_p \times d / 2+A \_c t \times(d+h / 2)$

y_bs $=\left(\right.$ A_p x d $\left./ 2+A \_c t \times(d+h / 2)\right) / A \_(c o m)$

y_bs $=\left(\left(4.678 \mathrm{~mm}^{\wedge} 2-x(300 \mathrm{~mm}) / 2\right)+(15.764,28\right.$

$\left.\left.\mathrm{mm}^{\wedge} 2 \quad \mathrm{x}(300 \mathrm{~mm}+(120 \mathrm{~mm}) / 2)\right)\right) /(20.442,28$

$\mathrm{mm}^{\wedge} 2$ ) y_bs $=311,944 \mathrm{~mm}$

Mencari jarak sisi atas profil baja terhadap garis netral balok induk komposit (yts) :

y_ts $=$ d-y_bs

y_ts $=300 \mathrm{~mm}-311,944 \mathrm{~mm}$

y_ts $=-11,944 \mathrm{~mm}$

Mencari jarak sisi atas slab beton terhadap garis netral balok induk komposit (ytc) :

y_tc $=\mathrm{h}+\mathrm{y} \_\mathrm{ts}$

y_tc $=120 \mathrm{~mm}-11,924 \mathrm{~mm}$

y_tc $=108,056 \mathrm{~mm}$ 
Mencari momen inersia penampang balok induk komposit (Icom) :

I_com $=\left(1 \times\right.$ be $\left.\times h^{\wedge} 3\right) /(12 \times n)+A$ ct $\times\left(y \_t c-\right.$ $\mathrm{h} / 2)^{\wedge} 2+\mathrm{I} \_\mathrm{p}+\mathrm{A} \_\mathrm{p} \times\left(\mathrm{d} / 2-\mathrm{y} \_\mathrm{ts}\right)^{\wedge} 2$

I_com $=(1 \times 1250 \mathrm{~mm} x \bar{\llbracket}(120 \mathrm{~mm}) \rrbracket \wedge 3) /(12 \mathrm{x}$ $9,515)+15.764,28 \mathrm{~mm}^{\wedge} 2$ x $(108,056 \mathrm{~mm}-(120$ $\mathrm{mm}) / 2)^{\wedge} 2+72.100 .000 \mathrm{~mm}^{\wedge} 4+4.678 \mathrm{~mm}^{\wedge} 2 \mathrm{x}$ $\left(300 / 2 \mathrm{~mm}^{\wedge} 2-(-11,944 \mathrm{~mm})\right)^{\wedge} 2$

I_com $=250.107 .767,1 \mathrm{~mm}^{\wedge} 4$

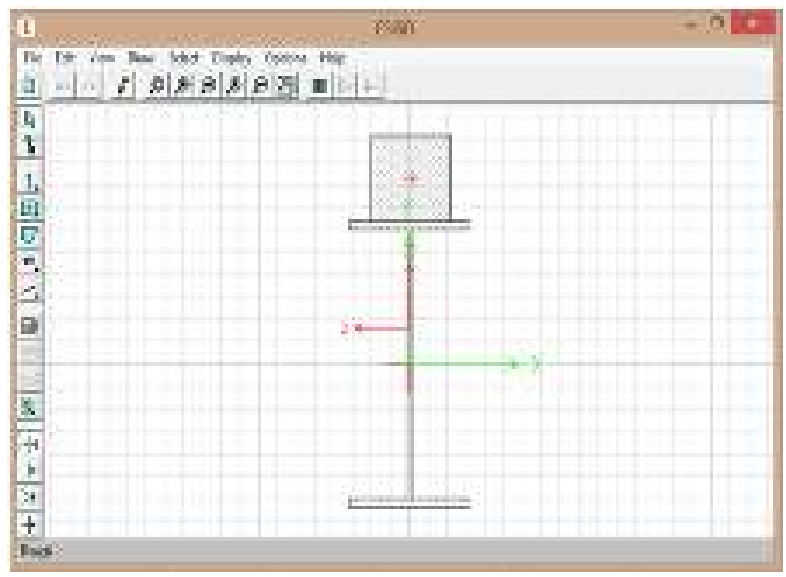

Gambar 4.9 Profil balok induk yang digunakan (WF 300.150.6,5.9)

Tabel 4.1 Section properties profil balok komposit pada gedung

\begin{tabular}{c|cccccccc}
\hline Ti & $H$ & $B$ & $t w$ & $t f$ & $t$ & $b e$ & $E_{s} /$ & $I_{c o m}$ \\
$p$ & $(m$ & $(m$ & $(m$ & $(m$ & $p e$ & $(m$ & $E_{c}$ & $\left(m^{4}\right)$ \\
$e$ & $m)$ & $m)$ & $m)$ & $m)$ & lat & $m)$ & & \\
& & & & & $(m$ & & & \\
& & & & & $m)$ & & & \\
\hline B & 30 & 15 & 6, & 9 & 12 & 1. & 9, & 250.1 \\
1 & 0 & 0 & 5 & & 0 & 25 & 51 & 07.76 \\
& & & & & & 0 & 5 & 7 \\
B & 20 & 10 & 5, & 8 & 12 & 1. & 9, & 96.62 \\
2 & 0 & 0 & 5 & & 0 & 25 & 51 & 8.509 \\
& & & & & & 0 & 5 & \\
\hline
\end{tabular}

\section{a. Ring balok}

Ring balok pada gedung berfungsi sebagai pengaku kontruksi rangka dan sebagai tumpuan dari rangka atap yang memikul beban penutup atap. Ring balok direncanakan menggunakan profil WF 250.125.5.8 untuk balok eksterior (menumpu beban kuda-kuda) dan profil WF 200.100.5,5.8 untuk balok interior

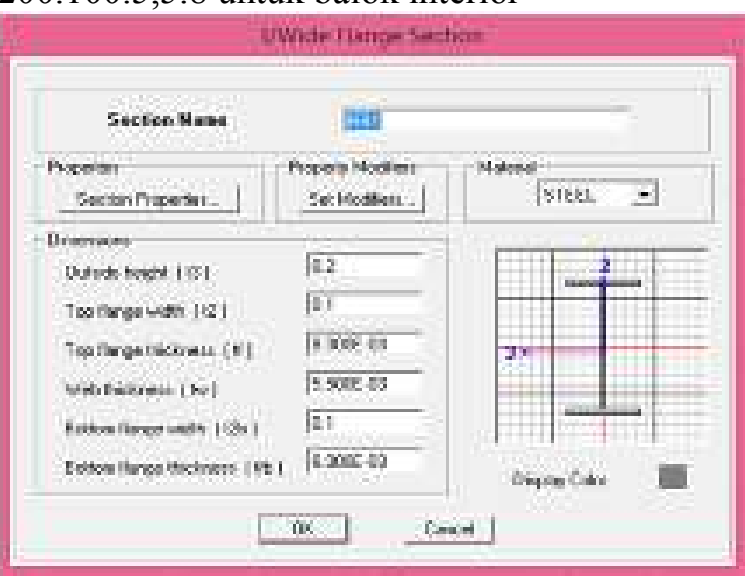

Gambar 4.10 Profil RB 1 (WF 200.100.5,5.8)

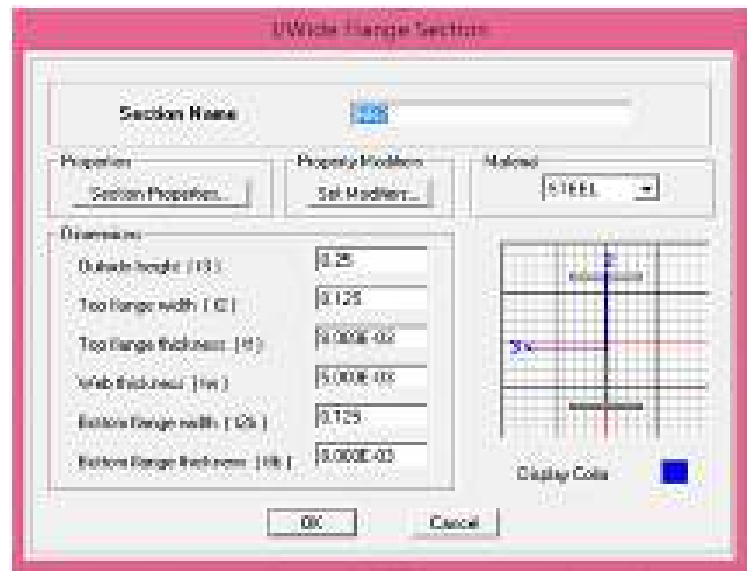

Gambar 4.11 Profil RB 2 (WF 250.125.5.8)

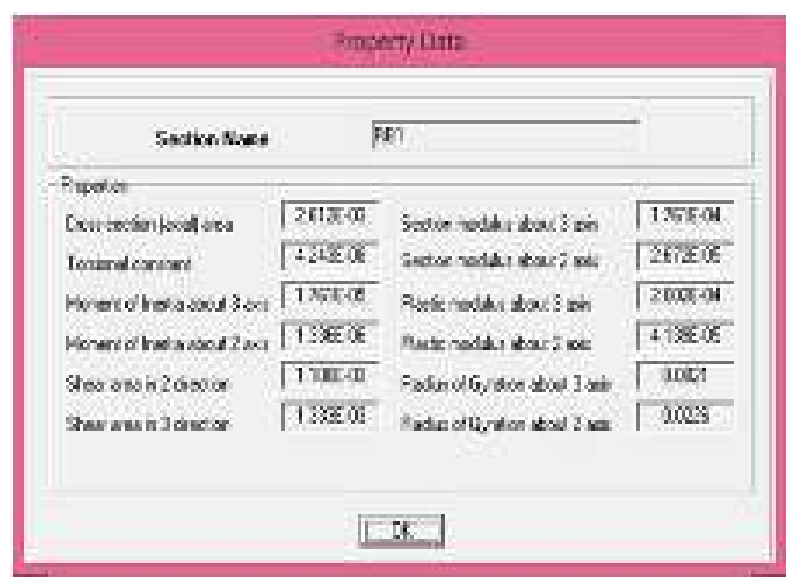

Gambar 4.12 Section properties WF 200.100.5,5.8 


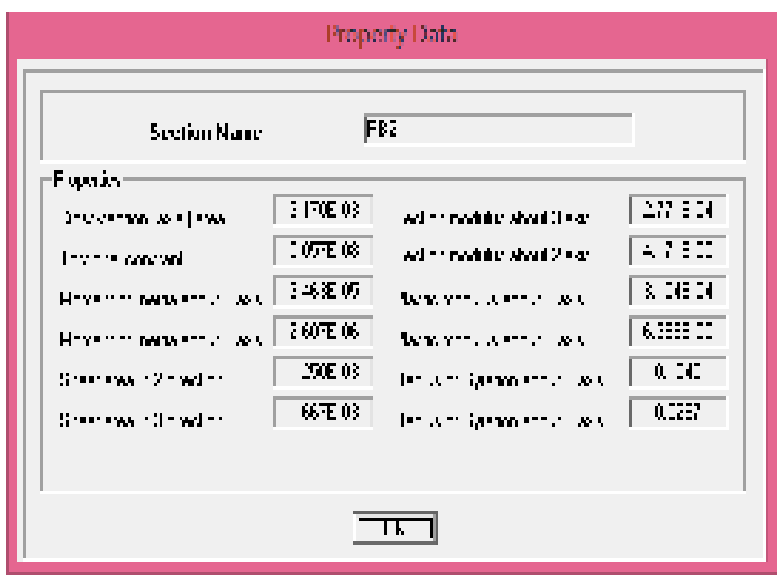

Gambar 4.13 Section properties WF 250.125.5.8

\section{b. Kolom baja komposit}

Kolom baja komposit dapat dibentuk dari pipa baja yang diisi dengan beton polos atau dapat pula dari profil baja hasil gilas panas yang dibungkus dengan beton dan diberi tulangan baja serta sengkang, seperti halnya pada kolom beton biasa. Analisis dari kolom komposit hampir sama dengan analisis komponen struktur tekan, namun dengan nilai fy, $\mathrm{E}$ dan $\mathrm{r}$ yang telah dimodifikasi. Pada perencanaan gedung ini, profil baja yang digunakan sebagai kolom baja komposit adalah WF 200.200.12.12. profil baja yang digunakan kemudian dibungkus oleh beton dengan dimensi kotor kolom sebesar 400 x $400 \mathrm{~mm} 2$ dengan kuat tekan beton sebesar $20 \mathrm{MPa}$. Kolom komposit ini juga diperkuat dengan 4 buah tulangan berdiameter $16 \mathrm{~mm}$ dan diberikan tulangan sengkang berpenampang 2, dengan diameter 8 $\mathrm{mm}$ dan jarak $250 \mathrm{~mm}$.

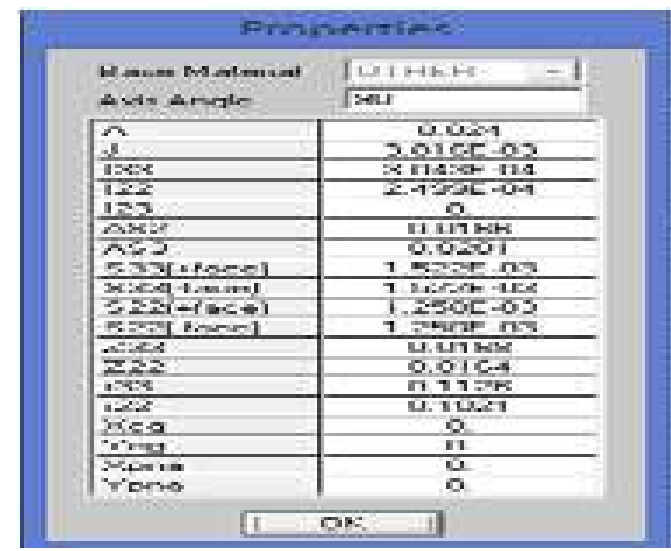

Gambar 4.14. Section properties penampang kolom komposit gedung

\section{Pembebanan Gravitasi}

Berdasarkan beban rencana pada kriteria desain, maka beban gravitasi tersebut akan di input ke dalam ETABS v.9.7.2 tanpa berat sendiri dari elemen-elemen struktur, karena pada ETABS v.9.7.2 sudah memperhitungkan berat sendiri struktur sesuai dengan dimensi elemen-elemen struktur yang digunakan.

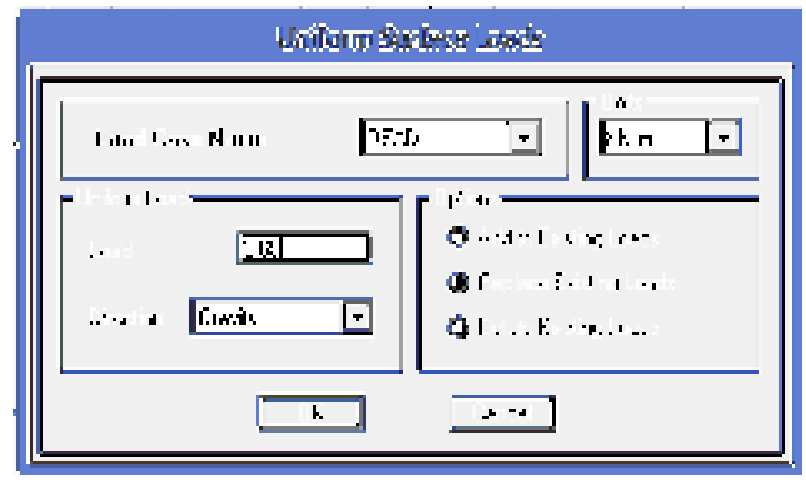

Gambar 4.14. Uniform surface loads dengan beban mati pada pelat

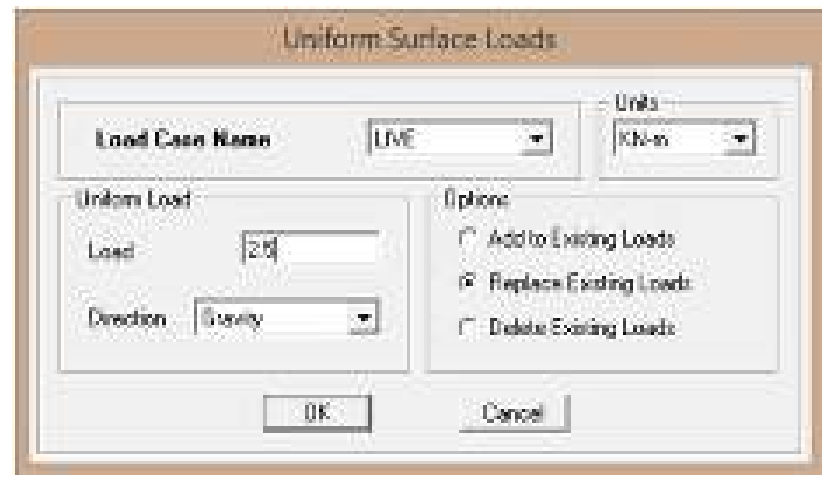

Gambar 4.15 Uniform surface loads dengan beban hidup pada pelat

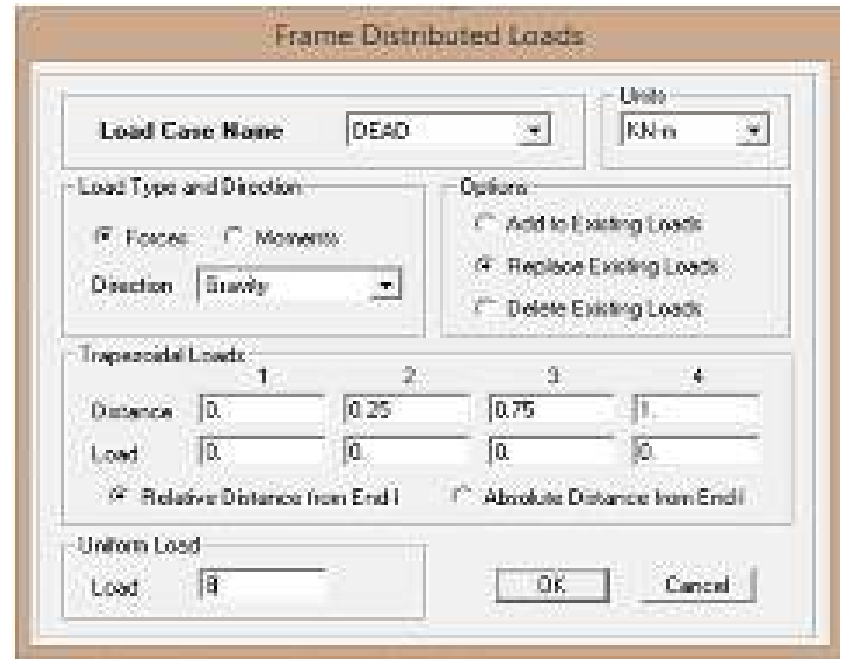

Gambar 4.15 Frame distributed loads dengan beban dinding pada balok 


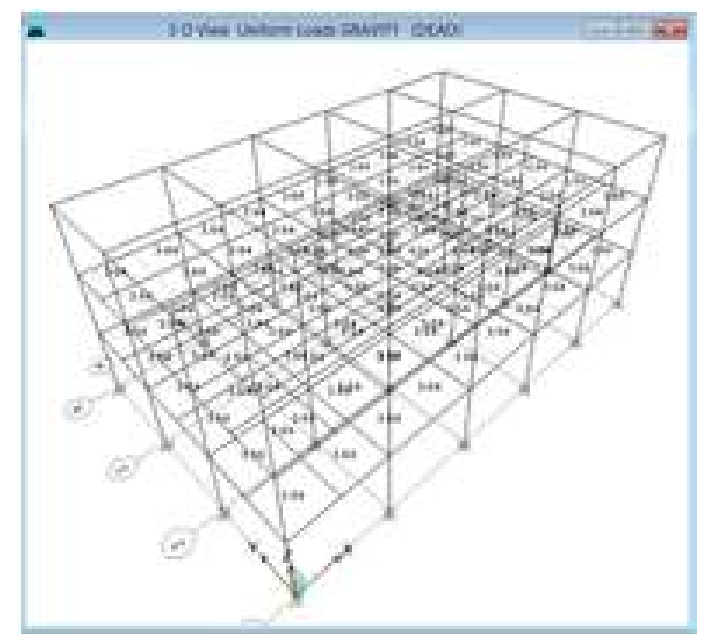

Gambar 4.16 Dead uniform loads pada pelat (satuan $\mathrm{kN}-\mathrm{m}$ )

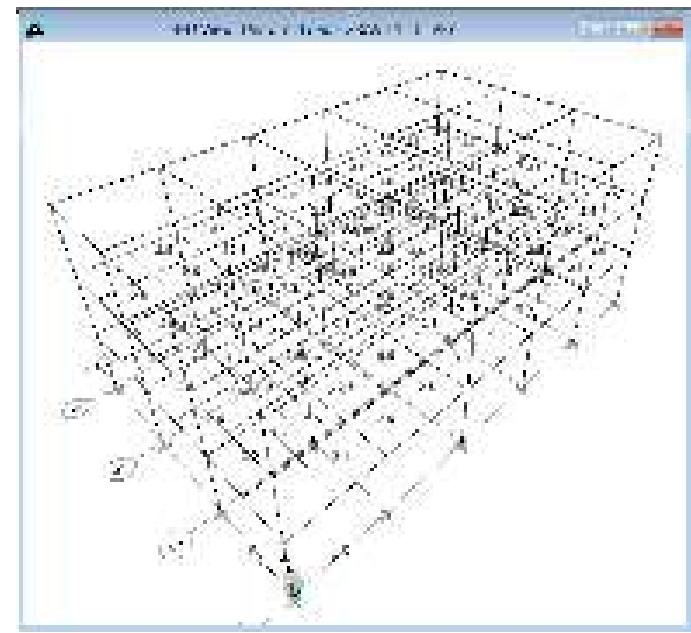

Gambar 4.17 Live uniform loads pada pelat (satuan $\mathrm{kN}-\mathrm{m}$ )

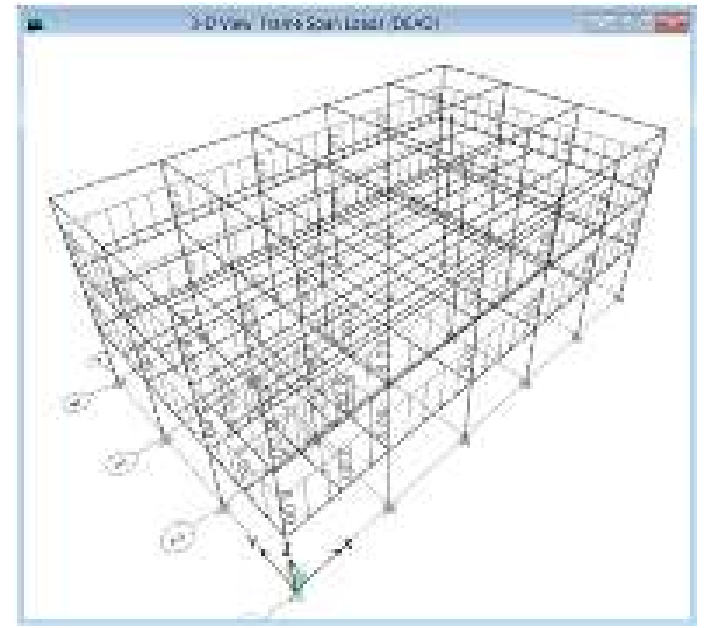

Gambar 4.18 Dead frame span loads pasangan dinding pada balok (satuan $\mathrm{kN}-\mathrm{m}$ )

\section{Pembebanan Gempa}

Selain beban gravitasi, gedung yang direncanakan ini ditinjau juga terhadap beban yang diakibatkan oleh gempa selama umur bangunan. Perencanaan struktur bangunan tahan gempa bertujuan untuk mencegah terjadinya keruntuhan struktur yang berakibat fatal pada saat terjadi gempa.

Berdasarkan Pedoman Perencanaan Ketahanan Gempa untuk Bangunan Gedung, SNI 03-17262002, kinerja struktur pada waktu menerima beban gempa dapat diklasifikasikan sebagai berikut :

a. Akibat gempa ringan, struktur bangunan tidak boleh mengalami kerusakan baik pada elemen strukturalnya maupun pada elemen non struktural. b. Akibat gempa sedang, elemen struktural bangunan tidak boleh rusak, tetapi elemen non strukturalnya boleh mengalami kerusakan ringan, namun struktur bangunan masih dapat dipergunakan.

c. Akibat gempa besar, baik elemen struktural maupun elemen non struktural bangunan akan mengalami kerusakan, tetapi bangunan tidak boleh runtuh.

6. Analisa Beban Gempa Statik Ekivalen Sistem struktur gedung adalah Sistem Rangka Pemikul Momen Menengah (SRPMM), dikarenakan gedung didirkan di atas wilayah gempa IV. Tinggi keseluruhan sistem rangka adalah 10,8 meter dari pengekang lateral. Langkah pertama dalam menentukan besarnya beban gempa statik ekivalen adalah menentukan waktu getar alami fundamental (T).

a. Menentukan waktu getar alami fundamental (T)

Ada beberapa cara pendekatan dalam menentukan waktu getar alami fundamental, Pedoman Perencanaan Ketahanan Gempa untuk Struktur Bangunan Gedung, SNI 03-1726-2002 , mensyaratkan bahwa waktu getar alami fundamental (T) tidak boleh melebihi 20\% dari TRayleigh dan untuk mencegah penggunaan struktur gedung yang terlalu fleksibel, maka $\mathrm{T}_{1}<\zeta \mathrm{n}$, dimana $\mathrm{n}$ adalah jumlah lantai dan koefisien $\zeta$ bergantung dari zona gempa seperti pada Tabel 4.2. 
Tabel 4.2 Koefisien $\zeta$ yang membatasi waktu getar alami fundamental struktur

\begin{tabular}{cc}
\hline Wilayah Gempa & $\boldsymbol{\zeta}$ \\
\hline $\mathbf{1}$ & 0,20 \\
\hline $\mathbf{2}$ & 0,19 \\
$\mathbf{3}$ & 0,18 \\
\hline $\mathbf{4}$ & 0,17 \\
\hline $\mathbf{5}$ & 0,16 \\
$\mathbf{6}$ & 0,15
\end{tabular}

Sumber : Pedoman Perencanaan Ketahanan Gempa untuk Struktur Bangunan Gedung, SNI 03-1726-2002

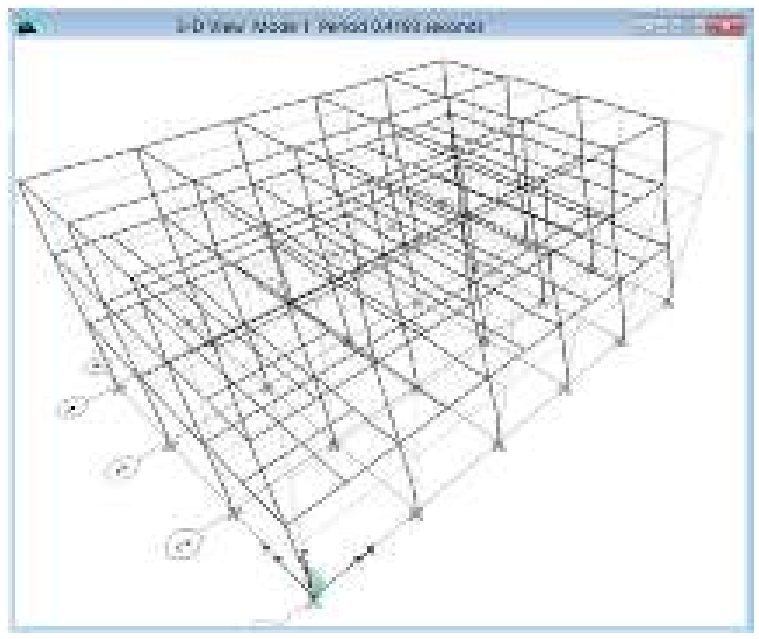

Gambar 4.19 Waktu getar struktur mode 1 (arah $\mathrm{x}$ ) dengan $\mathrm{T}_{1}=0,4193$ detik

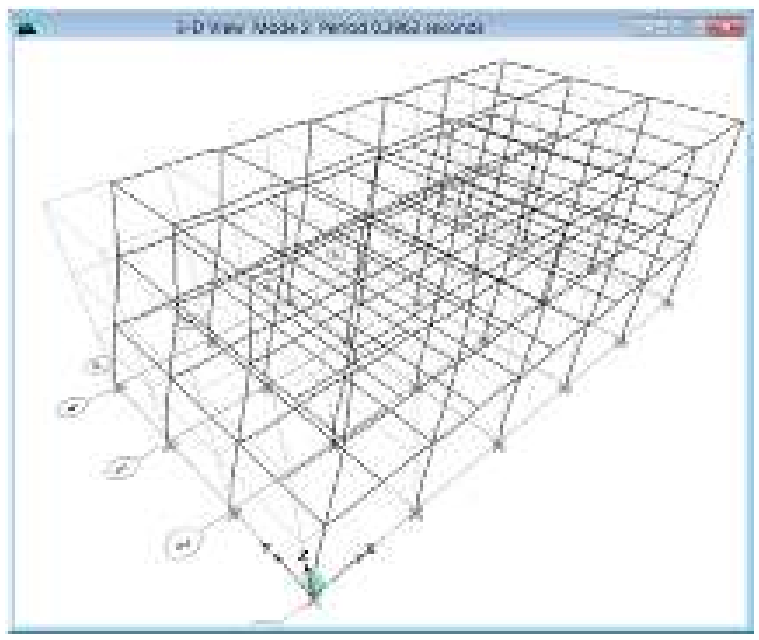

Gambar 4.20 Waktu getar struktur mode 2 (arah y) dengan $T_{1}=0,3962$ detik
Berdasarkan Tabel 4.2 di atas, diperoleh nilai $\zeta$ untuk wilayah gempa 4 sebesar 0,17 dan nilai $n$ berdasarkan jumlah tingkat adalah 3 , sehingga besar nilai $\zeta \mathrm{n}$ adalah sebesar 0,51 detik. Nilai T1 berdasar hasil ETABS adalah 0,4193 detik untuk arah $\mathrm{x}$ dan 0,3962 detik untuk arah y, sedangkan untuk pendekatan waktu getar struktur didapatkan sebesar 0,486 detik. Dari ketiga nilai tersebut diambil nilai $\mathrm{T} 1$ sebesar 0,486 detik, nilai ini kurang dari nilai $\zeta \mathrm{n}$ sebesar 0,51 detik, sehingga waktu getar struktur gedung memenuhi persyaratan dan gedung memiliki kekakuan yang cukup.

b. Menentukan faktor keutamaan (I)

Berdasarkan Pedoman Perencanaan Ketahanan Gempa untuk Struktur Bangunan Gedung, SNI 03-1726-2002 Pasal 4.1.2, disebutkan bahwa untuk berbagai kategori gedung, bergantung pada probabilitas terjadinya keruntuhan struktur gedung selama umur gedung dan umur gedung tersebut yang diharapkan, pengaruh gempa rencana terhadapnya harus dikalikan dengan suatu faktor keutamaan (Important Factor) atau I menurut persamaan I = I1 x I2.

Berdasarkan Pedoman Perencanaan Ketahanan Gempa untuk Struktur Bangunan Gedung, SNI 03-1726-2002 didapat faktor keutamaan (I) untuk Gedung Dinas Pertanian Tanaman Pangan dan Holtikultura Kabupaten Cianjur sebesar 1,0.

c. Menghitung berat struktur keseluruhan Berat total gedung $(\mathrm{Wt})$ akibat berat sendiri secara otomatis dapat dihitung oleh software ETABS v.9.7.2, namun untuk berat gedung tambahan seperti plesteran, dinding, dan beban hidup sebesar $30 \%$ harus diperhitungkan secara manual.

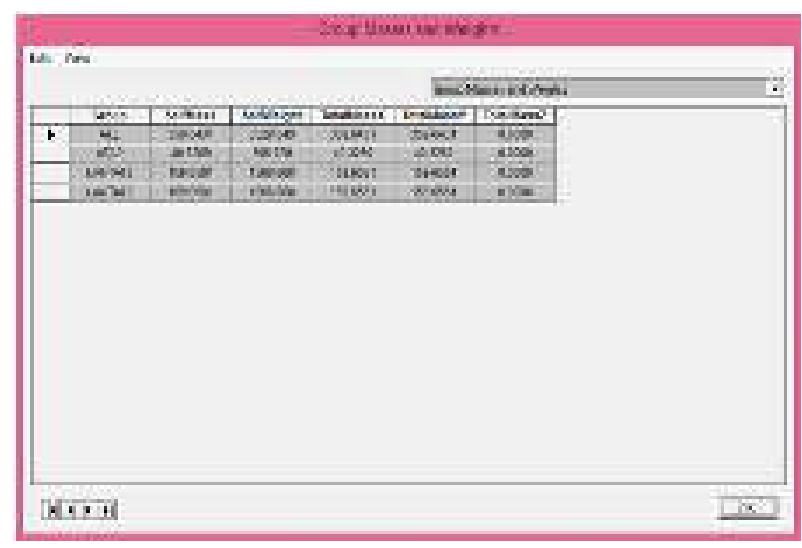

Gambar 4.21 Berat dan massa bangunan per lantai dari ETABS v.9.7.2 
Tabel 4.3. Berat masing-masing lantai dan berat struktur keseluruhan (Wt)

\begin{tabular}{lcccc}
\hline $\begin{array}{l}\text { Tingkat } \\
\text { Lantai }\end{array}$ & $\begin{array}{c}\text { Berat } \\
\text { Sendiri } \\
\text { Struktur }\end{array}$ & $\begin{array}{c}\text { Beban } \\
\text { Mati } \\
\text { Tambahan }\end{array}$ & $\begin{array}{c}\text { Beban } \\
\text { Hidup } \\
\text { Tambahan }\end{array}$ & $\begin{array}{c}\text { Total } \\
\text { Beban }\end{array}$ \\
\cline { 2 - 5 } Tingkat & $(\mathrm{kN})$ & $(\mathrm{kN})$ & $(\mathrm{kN})$ & $(\mathrm{kN})$ \\
ke 3 & 395,729 & 661,100 & 0,000 & $1.056,829$ \\
\hline Tingkat & $1.566,660$ & 1.805 & 281,250 & $3.652,910$ \\
ke 2 & & & & \\
\hline Tingkat & $1.566,660$ & 1.805 & 281,250 & $3.652,910$ \\
ke 1 & & & & \\
\hline \multicolumn{4}{c}{ Berat Struktur Keseluruhan $(\mathbf{W t})$} \\
\hline
\end{tabular}

d. Menghitung beban geser nominal (V)

Beban geser nominal untuk perhitungan gempa statik ekivalen dapat dihitung dengan rumus sebagai berikut :

$\mathrm{V}=\left(\mathrm{C} \_1 \times \mathrm{I} \times \mathrm{Wt}\right) / \mathrm{R}$

Dimana :

$\mathrm{C} 1=$ Nilai faktor respons gempa, yang ditentukan berdasarkan wilayah gempa, kondisi tanah dan waktu getar alami (T).

I $=$ Faktor keutamaan gedung sesuai

Tabel 4.2

$\mathrm{R} \quad=$ Faktor reduksi gedung

$\mathrm{Wt}=$ Berat struktur keseluruhan $(\mathrm{kN})$

Berdasarkan Tata Cara Perencanaan Ketahanan Gempa untuk Bangunan Gedung, SNI 03-17262002, faktor daktilitas (R) untuk Sistem Rangka Pemikul Momen Menengah (SRPMM) adalah 5,5. Berdasarkan data-data yang telah diperoleh, maka besarnya gaya geser nominal $(\mathrm{V})$ adalah :

$\mathrm{V}=(0,7 \times 1 \times 8.362,649) / 5,5$

$\mathrm{V}=1.064,337 \mathrm{kN}$

e. Menghitung besar gaya geser pada masingmasing tingkat $(\mathrm{F})$

Beban gempa nominal statik ekivalen yang bekerja pada pusat massa lantai di tingkat i dihitung dengan menggunakan persamaan :

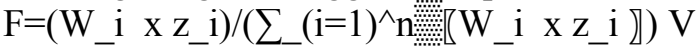

Dimana :

$\mathrm{Wi}=$ Berat lantai tingkat ke $\mathrm{i}$

$\mathrm{z} \quad=$ Ketinggian lantai tikngkat ke i

$\mathrm{n} \quad=$ Nomor lantai tingkat paling atas
Tabel 4.4 Gaya geser statik ekivalen per lantai

\begin{tabular}{ccccc}
\hline Tingkat & $\mathbf{z x}$ & $\mathbf{W x}$ & $\mathbf{W x . z x}$ & $\mathbf{F}$ \\
\cline { 2 - 5 } Lantai & $(\mathrm{m})$ & $(\mathrm{kN})$ & $(\mathrm{kN} . \mathrm{m})$ & $(\mathrm{kN})$ \\
\hline $\begin{array}{c}\text { Tingkat } \\
\text { ke 3 }\end{array}$ & 10,8 & $1.056,829$ & $11.413,753$ & 238,411 \\
\hline $\begin{array}{c}\text { Tingkat } \\
\text { ke 2 }\end{array}$ & 7,2 & $3.652,910$ & $26.300,952$ & 550,262 \\
\hline $\begin{array}{c}\text { Tingkat } \\
\text { ke 1 }\end{array}$ & 3,6 & $3.652,910$ & $13.150,476$ & 275,664 \\
\hline $\mathbf{\Sigma}$ & & $8.362,649$ & $50.865,181$ & $1.064,337$
\end{tabular}

\section{Hasil Analisa Struktur}

Berdasarkan hasil analisa struktur yang telah dilakukan menggunakan bantuan software ETABS v.9.7.2, didapatkan besaran gaya-gaya dalam (momen, aksial dan geser) yang berbedabeda sesuai dengan kombinasi pembebanan. Gaya dalam terbesar hasil analisa software ETABS v.9.7.2 selanjutnya akan dijadikan sebagai gaya dalam untuk pengecekan elemen-elemen struktur yang bekerja pada balok, kolom berikut sambungan elemen-elemen struktur, sedangkan untuk reaksi perletakan dari struktur akan dijadikan sebagai acuan untuk menentukan jenis dan ukuran pondasi.

Selain memperhitungkan gaya dalam hasil dari gaya luar yang bekerja pada gedung, hasil analisa struktur juga adalah untuk mengetahui kinerja struktur gedung, yaitu kinerja batas layan dan kinerja batas ultimit. Berdasarkan Tata Cara Perencanaan Ketahanan Gempa untuk Bangunan Gedung, SNI 03-1726-2002, kinerja batas layan gedung menurut Pasal 8.1.2, simpangan antar tingkat tidak boleh melampaui 0,03 / R kali tinggi tingkat yang bersangkutan atau $30 \mathrm{~mm}$ bergantung yang mana merupakan nilai yang terkecil. Untuk kinerja batas ultimit menurut Pasal 8.2.2, dalam segala hal simpangan antar tingkat yang dihitung dari simpangan gedung menurut Pasal 8.2.1 tidak boleh melampaui 0,02 kali tinggi tingkat yang bersangkutan.

a. Perhitungan Biaya Pekerjaan Elemen-elemen Struktur Primer

Pada tahapan ini, akan dilalukan perhitungan biaya pekerjaan struktur. Tahapan ini merupakan tahapan akhir dari Laporan Tugas Akhir. Biaya pekerjaan struktur dihitung berdasarkan analisa harga satuan Standar Nasional Indonesia (SNI). Perhitungan biaya pekerjaan struktur disajikan 
dalam Rencana Anggaran Biaya (RAB) untuk struktur eksisting dan juga struktur baru, sedangkan untuk analisa harga satuan. Perhitungan biaya struktur dilakukan secara terpisah. Berikut ini adalah hasil perhitungan biaya pekerjaan struktur primer eksisting.

Tabel 4.5. Rekapitulasi biaya pekerjaan struktur primer eksisting

\begin{tabular}{|c|c|c|}
\hline 6 & 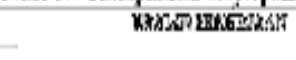 & 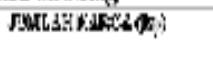 \\
\hline$T$ & & $T$ \\
\hline & \multicolumn{2}{|c|}{ 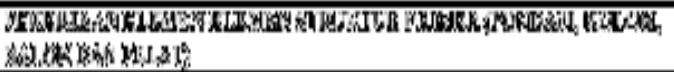 } \\
\hline$T$ & 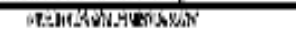 & 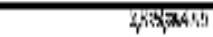 \\
\hline$\ddot{i}$ & 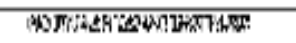 & 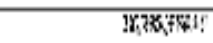 \\
\hline \multirow[t]{2}{*}{5} & 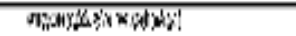 & 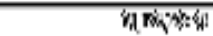 \\
\hline & 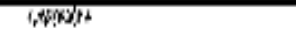 & \\
\hline \multirow[t]{2}{*}{5} & 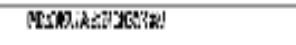 & 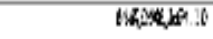 \\
\hline & 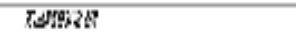 & \\
\hline \multirow[t]{2}{*}{$\sqrt{3}$} & MaWkWLWWH & 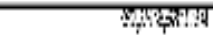 \\
\hline & Foreus & \\
\hline \multirow[t]{2}{*}{6} & 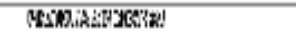 & 14actsos \\
\hline & & 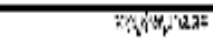 \\
\hline
\end{tabular}

Perhitungan biaya elemen-elemen struktur primer yang baru dilakukan berdasarkan hasil desain struktur yang telah dilakukan. Berikut ini adalah hasil perhitungan biaya pekerjaan struktur primer baru :

Tabel 4.6 Rekapitulasi biaya pekerjaan struktur primer baru

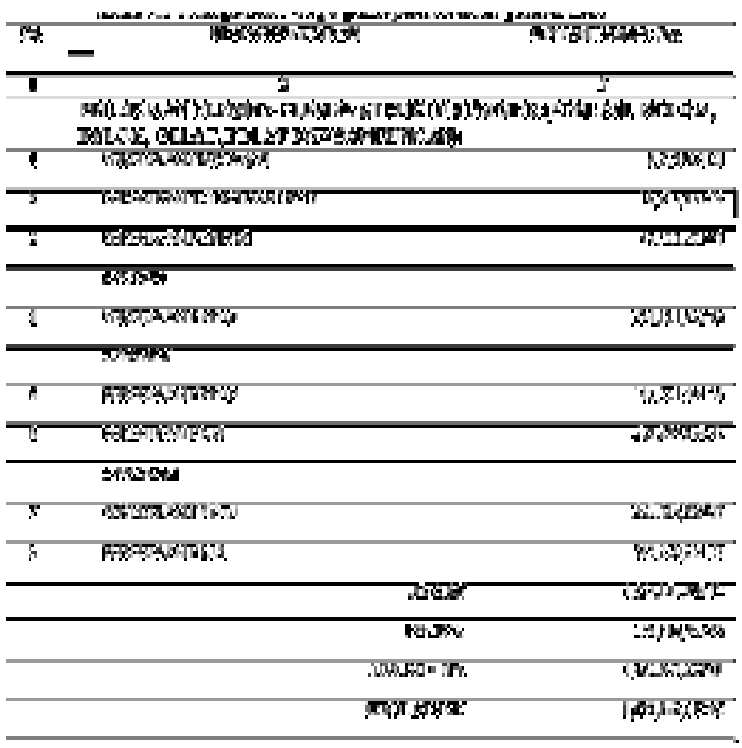

\section{KESIMPULAN}

a. Resume Design

Berdasarkan hasil perencanaan struktur baja komposit yang telah dilakukan, didapatkan dimensi profil baja pengganti dimensi elemen-elemen struktur beton dari desain eksisting. Berikut ini merupakan hasil desain konstruksi Gedung Dinas Pertanian Tanaman Pangan dan Holtikultura Kabupaten Cianjur dengan menggunakan konstruksi beton dan konstruksi baja komposit :

Tabel 5.1 Resume desain eksisting dan desain baru

\begin{tabular}{|c|c|c|}
\hline $\begin{array}{l}\text { Elemen } \\
\text { struktur }\end{array}$ & $\begin{array}{l}\text { Hasil desain } \\
\text { eksisting(Konstruk } \\
\text { si beton bertulang) }\end{array}$ & $\begin{array}{l}\text { Hasil desain baru } \\
\text { (Konstruksi baja } \\
\text { komposit) }\end{array}$ \\
\hline $\begin{array}{l}\text { Balok } \\
\text { induk }\end{array}$ & $\begin{array}{l}\text { Uk. } 20 \times 45 \mathrm{~cm}^{2}, \\
9 \mathrm{D} 16 ; \varnothing 8-100 \& \\
150\end{array}$ & $\begin{array}{l}\text { WF300.150.6,5.9, } \\
\text { Shear connector } \\
\varnothing 19-350\end{array}$ \\
\hline $\begin{array}{l}\text { Balok } \\
\text { anak }\end{array}$ & $\begin{array}{l}\text { Uk. } 20 \times 35 \mathrm{~cm}^{2}, \\
\text { 9D16; Ø8-100\& } \\
150\end{array}$ & $\begin{array}{l}\text { WF } 200.100 .5,5.8 \text {, } \\
\text { Shear connector } \\
\varnothing 19-600\end{array}$ \\
\hline Kolom & $\begin{array}{l}\text { Uk. } 40 \times 40 \mathrm{~cm}^{2}, \\
8 \mathrm{D} 16 ; \varnothing 8-100\end{array}$ & $\begin{array}{l}\text { Uk. } 40 \times 40 \mathrm{~cm}^{2}, \\
\text { WF200.200.12.12, } \\
\text { 4D16; Ø8-250 }\end{array}$ \\
\hline Pelat & $\begin{array}{l}\text { Tebal } 12 \mathrm{~cm} \text {, } \\
\varnothing 8-150 \text {, rangkap }\end{array}$ & $\begin{array}{l}\text { Bondek tebal } 0,75 \\
\mathrm{~mm} \text {; } \\
\text { WM } 8-150\end{array}$ \\
\hline Sloof & $\begin{array}{l}\text { Uk. } 20 \times 30 \mathrm{~cm}^{2}, \\
4 \mathrm{D} 16 ; \varnothing 8-100 \& \\
150\end{array}$ & $\begin{array}{l}\text { Uk. } 20 \times 30 \mathrm{~cm}^{2}, \\
\text { 4D } 16 ; \varnothing 8-100 \\
\& 150\end{array}$ \\
\hline $\begin{array}{l}\text { Ring } \\
\text { balok }\end{array}$ & $\begin{array}{l}\text { Uk. } 20 \times 30 \mathrm{~cm}^{2} \text {, } \\
\text { 4D } 16: \varnothing 8-100 \& \\
\text { 150 }\end{array}$ & $\begin{array}{l}\text { WF 200.100.5,5.8 } \\
\text { (interior), } \\
\text { WF 250.125.5.8 } \\
\text { (eksterior) }\end{array}$ \\
\hline Pondasi & $\begin{array}{l}\text { Uk. } 200 \text { x } 200 \times 35 \\
\mathrm{~cm}^{3} \\
\text { D16-200, arah x } \\
\text { dan y }\end{array}$ & $\begin{array}{l}\text { Uk. } 200 \times 200 \times \\
35 \mathrm{~cm}^{3} \\
\text { D16-180, arah x } \\
\text { dan y }\end{array}$ \\
\hline
\end{tabular}

Berikut ini merupakan hasil perhitungan sambungan elemen-elemen struktur baja :

- Sambungan balok anak ke balok induk :

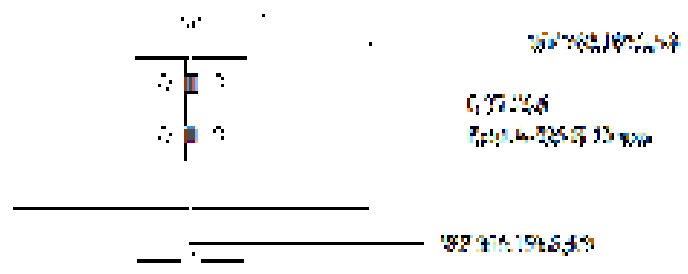

Gambar 5.1 Detail sambungan balok anak ke balok induk 
- Sambungan balok induk ke kolom :

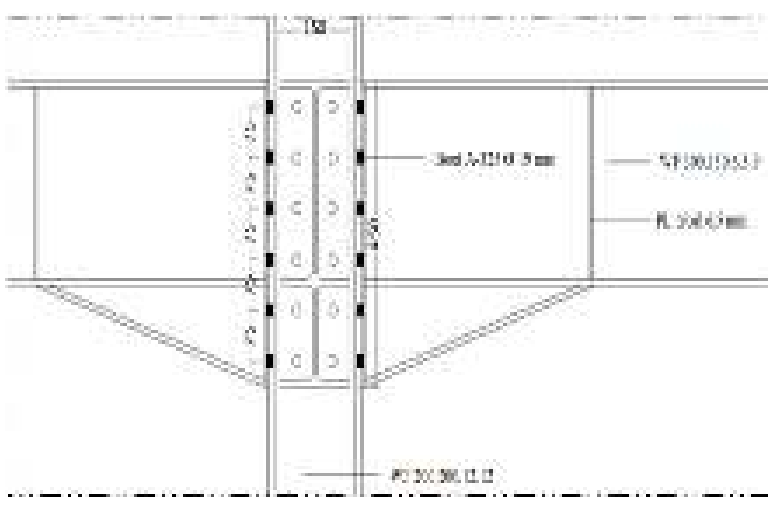

Gambar 5.2 Detail sambungan balok-kolom Sambungan kolom ke pedestal

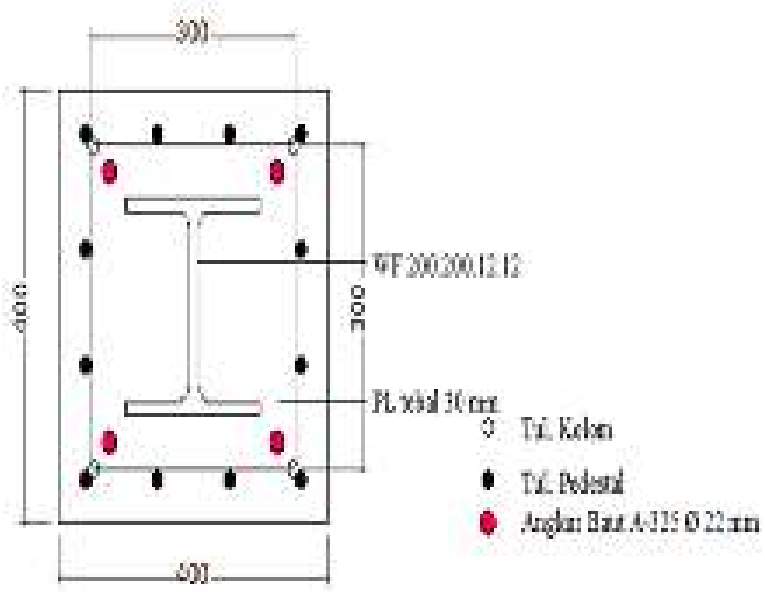

Gambar 5.3 Detail melintang base plate

\section{b. Resume Biaya}

Berikut ini merupakan Rencana Anggaran Biaya (RAB) pekerjaan elemen-elemen struktur primer untuk desain eksisting menggunakan beton bertulang dan desain baru menggunakan baja komposit.

Tabel 5.2 Resume biaya pekerjaan elemenelemen struktur keseluruhan gedung

\begin{tabular}{lcc}
\hline $\begin{array}{c}\text { Elemen } \\
\text { struktur }\end{array}$ & $\begin{array}{c}\text { Konstruksi } \\
\text { beton } \\
\text { bertulang } \\
\text { (Rp.) }\end{array}$ & $\begin{array}{c}\text { Konstruksi baja } \\
\text { komposit (Rp.) }\end{array}$ \\
\hline Pondasi & $86,976,888.00$ & $91,131,336.00$ \\
\hline Sloof & $64,399,466.40$ & $64,399,466.40$ \\
\hline Pedestal & - & $41,812,995.46$ \\
\hline Kolom & $185,655,862.46$ & $425,022,074.10$ \\
\hline $\begin{array}{l}\text { Balok } \\
\text { induk }\end{array}$ & $156,974,305.04$ & $364,491,041.20$ \\
\hline
\end{tabular}

\begin{tabular}{lcc}
\hline $\begin{array}{l}\text { Balok } \\
\text { anak }\end{array}$ & $76,110,044.58$ & $93,397,017.46$ \\
\hline Pelat & $363,061,939.34$ & $267,065,966.96$ \\
\hline $\begin{array}{l}\text { Ring } \\
\text { balok }\end{array}$ & $64,399,466.40$ & $115,006,595.00$ \\
\hline
\end{tabular}

Berdasarkan hasil perencanaan struktur bangunan Gedung Dinas Pertanian Tanaman Pangan dan Holtikultura Kabupaten Cianjur yang baru, dengan menggunakan struktur baja komposit diperoleh beberapa kesimpulan sebagai berikut :

a. Pondasi foot plat yang baru memiliki dimensi yang sama dengan desain eksisting, namun tulangan yang digunakan berbeda. Tulangan hasil desain pondasi eksisting menggunakan tulangan D16 - 200 dan tulangan hasil desain pondasi baru menggunakan tulangan D16 180. Biaya pekerjaan seluruh pondasi foot plat hasil desain baru adalah Rp. 91,131,336.00, sedangkan untuk hasil desain eksisting adalah Rp. 86,976,888.00. Biaya pekerjaan pondasi hasil desain baru lebih mahal dikarenakan jarak tulangan hasil desain lebih rapat dibandingkan desain eksisting.

b. Sloof yang digunakan pada desain struktur yang baru memiliki dimensi dan penulangan yang sama dengan desain eksisting. Ukuran sloof yang digunakan adalah ukuran $200 \mathrm{x}$ $300 \mathrm{~mm} 2$ dan tulangan yang digunakan adalah 4 D16 untuk tulangan utamanya dan tulangan sengkang $\varnothing 8-100$ untuk daerah tumpuan, sedangkan untuk daerah lapangan digunakan tulangan $\varnothing 8-150$. Biaya pekerjaan sloof untuk keseluruhan gedung untuk desain struktur baru dan eksisting adalah Rp. 64,399,466.40.

c. Pada desain yang baru, digunakan pedestal sebagai penghubung antara pondasi foot plat dengan kolom komposit. Untuk desain eksisting tidak digunakan pedestal, karena kolom yang digunakan merupakan kolom beton typical dari pangkal kolom (ujung foot plat) hingga ke ujung kolom. Tulangan yang digunakan untuk pedestal adalah 12 D16 untuk tulangan utama dan Ø8 - 100 untuk tulangan sengkang. Biaya pekerjaan pedestal untuk keseluruhan gedung adalah sebesar Rp. 41,812,995.46.

d. Kolom komposit yang digunakan memiliki dimensi kotor yang sama dengan dimensi kolom eksisting, yaitu 400 x $400 \mathrm{~mm} 2$. Kolom baja yang digunakan adalah WF 200.200.12.12, dengan tulangan utama 4 D16 dan sengkang $\varnothing 8-250$. Kolom eksisting 
yang digunakan menggunakan tulangan 8 D16, dengan tulangan sengkang Ø8 - 100 . Biaya pekerjaan kolom komposit untuk keseluruhan gedung lebih mahal dibandingkan biaya pekerjaan kolom menggunakan struktur beton bertulang. Harga pekerjaan kolom komposit untuk keseluruhan gedung adalah Rp. 425,022,074.10, sedangkan untuk kolom beton bertulang adalah Rp. 185,655,862.46.

e. Balok induk yang digunakan berdasarkan hasil desain struktur yang baru adalah WF 300.150.6,5.9, dengan menggunakan shear connector Ø19 - 350. Dimensi balok induk hasil desain struktur eksisting adalah $200 \mathrm{x}$ $450 \mathrm{~mm} 2$, dengan tulangan utama $9 \mathrm{D} 16$, sengkang Ø8 - 100 untuk daerah tumpuan dan $\varnothing 8$ - 150 untuk daerah lapangan. Biaya pekerjaan balok induk yang baru untuk keseluruhan gedung adalah $\mathrm{Rp}$. $364,491,041.20$, biaya ini jauh lebih mahal dibandingkan desain struktur eksisting sebesar Rp. 156,974,305.04.

f. Balok anak yang digunakan berdasarkan hasil desain struktur yang baru adalah WF 200.100.5,5.8, dengan menggunakan shear connector $\varnothing 19-600$. Dimensi balok induk hasil desain struktur eksisting adalah $200 \mathrm{x}$ $350 \mathrm{~mm} 2$, dengan tulangan utama $9 \mathrm{D} 16$, sengkang Ø8 - 100 untuk daerah tumpuan dan $\varnothing 8$ - 150 untuk daerah lapangan. Biaya pekerjaan balok anak yang baru untuk keseluruhan gedung adalah $\mathrm{Rp}$. 93,397,017.46, biaya ini lebih mahal dibandingkan desain struktur eksisting sebesar Rp. 76,110,044.58.

g. Pelat lantai hasil desain struktur baru menggunakan bondek dengan ketebalan 0,75 $\mathrm{mm}$ dan tebal kotor pelat $120 \mathrm{~mm}$, dengan tulangan wire mesh M $8-150$. Pelat desain struktur eksisting menggunakan beton konvensional dengan tebal $120 \mathrm{~mm}$ dan tulangan rangkap Ø8-150. Biaya pekerjaan pelat berdasarkan hasil desain struktur baru lebih murah dibandingkan hasil desain struktur eksisting, yaitu sebesar Rp. 267,065,966.96 dan Rp. 363,061,939.34 untuk desain pelat eksisting.

h. Ring balok yang digunakan berdasarkan hasil desain struktur baru digunakan WF 250.125.5.8, untuk balok eksterior yang memikul beban kuda-kuda dan WF 200.100.5,5.8 untuk balok interior. Pada desain struktur eksisting digunakan ring balok beton dengan dimensi 200 x $300 \mathrm{~mm} 2$, tulangan utama 4 D16, sedangkan untuk tulangan sengkang digunakan Ø8-100 untuk daerah tumpuan dan $\varnothing 8-150$ untuk daerah lapangan. Biaya pekerjaan ring balok yang baru untuk keseluruhan gedung adalah Rp. $115,006,595.00$, biaya ini jauh lebih mahal dibandingkan desain struktur eksisting sebesar Rp. 64,399,466.40.

\section{DAFTAR PUSTAKA}

Anonim, Tata Cara Perencanaan Ketahanan Gempa Untuk Bangunan Gedung, Badan Standarisasi Nasional, Jakarta, 2002.

Anonim, Tata Cara Perencanaan Struktur Baja Untuk Bangunan Gedung, Badan Standarisasi Nasional, Jakarta, 2002.

Das, Braja, Principles of Foundation Engineering, Cengage Learning, USA, 2011.

Doris Antoni dan Adhika Setyo N, Laporan Tugas Akhir Perencanaan Struktur Gedung Apartemen Salemba Residences, ITB, Bandung, 2007.

Griffis, Lawrence G, Load and Resistance Factor Design of W-Shape Encased in Concrete, American Institue of Steel Construction, Chicago, U.S.A, 1992.

Gunawan, Rudi, Tabel Profil Konstruksi Baja, Penerbit Kanisius, Yogyakarta, 1987.

Imran, Iswandi, Perencanaan Struktur Gedung Beton Bertulang Tahan Gempa, Penerbit ITB, Bandung, 2010.

Indraharja, Ferry, Modifikasi Perencanaan Struktur Baja Komposit Pada Gedung Perpustakaan Universitas Negeri Jember, ITS, Surabaya, 2011.

Mc. Cormac, Jack C, Structural Steel Design LRFD Method Second Edition, Harper Collins College Publisher, New York, 1995.

Nakazawa, Kazuto, Mekanika Tanah \& Teknik Pondasi, PT. Pradnya Paramita, Jakarta, 2000.

Oentoeng, Konstruksi Baja, Penerbit ANDI Yogyakarta, Yogyakarta, 2000.

R. Amon, B. Knobloch dan A. Mazumder, Perencanaan Konstruksi Baja Untuk Insinyur dan Arsitek, PT. Pradnya Paramita, Jakarta, 1998. 
Segui, William T, Steel Design Fourth Edition, Thomson, Canada, 2007.

Taranath, Bungale S, Structural Analysis and Design of Tall Builings for Stell and Composite Construction, CRC Press, Las Vegas, U.S.A, 2012.

URL: http://mnoerilham.blogspot.com, 25 Pebruari 2019 